\title{
Correlates of illness severity in infectious mononucleosis
}

\author{
John Odame ${ }^{1}$, Joan Robinson MD FRCPC ${ }^{2}$, Nasser Khodai-Booran $\mathrm{PhD}^{1}$, Simon Yeung BSc ${ }^{1}$, \\ Tony Mazzulli MD FRCPC ${ }^{3}$, Derek Stephens $\mathrm{MSc}^{4}$, Upton D Allen MBBS MSc FRCPC ${ }^{1,4}$
}

\begin{abstract}
J Odame, J Robinson, N Khodai-Booran, et al. Correlates of illness severity in infectious mononucleosis. Can J Infect Dis Med Microbiol 2014;25(5):277-280.
\end{abstract}

INTRODUCTION: Understanding the spectrum and frequencies of Epstein-Barr virus (EBV) complications and markers of illness severity in immunocompetent patients with primary EBV infection will inform management of patients with EBV-related illnesses.

OBJECTIVES: To determine the clinical and laboratory correlates of illness severity among infants, children and youth with infectious mononucleosis (IM).

METHODS: Study subjects with confirmed IM were prospectively enrolled. Illness severity was assessed at baseline and at six weeks using a scoring tool. Peripheral blood viral loads served as a measure of viral burden.

RESULTS: Among 32 children and young adults with IM, the median age was 16 years (range two to 24 years). The predominant clinical findings were lymphadenopathy (23 of 32 [72\%]), pharyngitis (16 of 32 [50\%]), fever (nine of 32 [28\%]) and splenomegaly (six of 32 [19\%]). With respect to symptoms or signs that persisted to at least six weeks after illness onset, the predominant complaint was lymphadenopathy in $35 \%$ of subjects available for reassessment. Deranged liver function tests were present at presentation in up to $44 \%$ of subjects. Patients with the highest viral loads at presentation had significantly higher illness severity scores associated with fatigue $(\mathrm{P}=0.02)$. Other than the scores associated with fatigue, viral load values were not significantly correlated with the illness severity scores at baseline and at six weeks.

CONCLUSION: In IM, viral loads are not necessarily correlated with illness severity, with the exception of fatigue. EBV-related hepatitis is common in IM, confirming the status of this virus as a relatively common cause of transient hepatitis in children and youth. This entity is not necessarily a marker of disease severity.

Key Words: Epstein-Barr virus; Hepatitis; Mononucleosis; Viral load

Tnfectious mononucleosis (IM) results from primary infection by 1 the Epstein-Barr virus (EBV). EBV is a double-stranded DNA gamma herpesvirus that was first isolated in 1964 from Burkitt lymphoma tissue (1). Humans are the only source of EBV and the virus has a worldwide distribution, with seropositivity rates of $90 \%$ among adults.

In most nonindustrialized communities, primary EBV infection is usually asymptomatic and occurs within the first three years of life $(2-7)$. In industrialized countries, infection is often delayed until the second decade of life or later $(4,8)$, where clinical illness is typically characterized by IM. This entity is usually characterized by fever,

\section{Des corrélats de la gravité de la maladie en cas de mononucléose infectieuse}

INTRODUCTION : Il faut comprendre le spectre et la fréquence des complications et des marqueurs de gravité du virus d'Epstein-Barr (VEB) chez les patients immunocompétents atteints d'une infection primaire par le VEB pour étayer la prise en charge des patients ayant une maladie liée à ce virus.

OBJECTIFS : Déterminer les corrélats cliniques et de laboratoire de gravité de la maladie chez des nourrissons, des enfants et des adolescents atteints de mononucléose infectieuse (MI).

MÉTHODOLOGIE : Les sujets atteints d'une MI confirmée ont été enrôlés prospectivement dans l'étude. Les chercheurs ont évalué la gravité de la maladie en début d'étude et au bout de six semaines au moyen d'un outil d'évaluation. Les charges virales du sang périphérique ont été utilisées pour mesurer le fardeau viral.

RÉSULTATS : Les 32 enfants et jeunes adultes atteints de MI avaient un âge médian de 16 ans (plage de deux à 24 ans). Les principales observations cliniques étaient une lymphadénopathie (23 cas sur 32 [72\%]), une pharyngite (16 sur 32 [50\%]), de la fièvre (neuf sur 32 [28 \%]) et une splénomégalie (six sur 32 [16 \%]). Parmi les signes ou symptômes qui ont persisté au moins six semaines après l'apparition de la maladie, la lymphadénopathie était le principal problème chez $35 \%$ des sujets disponibles pour être réévalués. Jusqu'à $44 \%$ des sujets présentaient des anomalies dans les tests de fonction hépatique. Les patients dont la charge virale était la plus élevée à la présentation obtenaient des indices de gravité de la maladie associée à la fatigue considérablement plus marqués $(P=0,02)$. À part les indices associés à la fatigue, les valeurs de la charge virale n'avaient pas de corrélation significative avec les indices de gravité de la maladie en début d'étude et au bout de six semaines.

CONCLUSION : En cas de MI, les charges virales ne sont pas nécessairement corrélées avec la gravité de la maladie, à l'exception de la fatigue. L'hépatite liée au VEB est courante en présence de MI. Ainsi, ce virus est une cause relativement fréquente d'hépatite transitoire chez les enfants et les adolescents. Cette entité n'est pas nécessairement un marqueur de gravité de la maladie.

exudative pharyngitis, lymphadenopathy, hepatosplenomegaly and atypical lymphocytosis. Complications may occur, resulting in a spectrum of clinical entities manifested by specific organ dysfunction syndromes (eg, hepatitis), and hematological and biochemical abnormalities (9-12) in individuals with presumably normal immune systems. An understanding of the spectrum and frequencies of EBV complications and markers of illness severity in these subjects will inform management of patients with EBV-related illnesses.

In the above context, the goal of the present study was to determine the clinical and laboratory correlates of illness severity among infants, children and youth with IM.

\footnotetext{
${ }^{1}$ Division of Infectious Diseases, Hospital for Sick Children, Toronto, Ontario; ${ }^{2}$ Division of Infectious Diseases, Stollery Children's Hospital,

University of Alberta, Edmonton, Alberta; ${ }^{3}$ Mount Sinai Hospital, University of Toronto; ${ }^{4}$ The Research Institute, Hospital for Sick Children, Toronto, Ontario

Correspondence: Dr Upton D Allen, Division of Infectious Diseases, Hospital for Sick Children, 555 University Avenue, Toronto, Ontario M5G 1X8. Telephone 416-813-8129, fax 416-803-8404, e-mail upton.allen@sickkids.ca
} 
TABLE 1

Frequency of symptoms and signs of infectious mononucleosis

\begin{tabular}{lcc}
\hline Symptoms & Baseline visit (n=32) & $\begin{array}{c}\text { Six-week } \\
\text { follow-up visit* }\end{array}$ \\
\hline Lymphadenopathy & $23(72)$ & $7(35)$ \\
Pharyngitis & $16(50)$ & $1(5)$ \\
Fever & $9(28)$ & $0(0)$ \\
Splenomegaly & $6(19)$ & $2(10)$ \\
Hepatomegaly & $2(6)$ & $0(0)$ \\
Jaundice & $1(3)$ & $0(0)$ \\
Fatigue & $21(66)$ & $4(16)$ \\
Somnolence & $17(53)$ & $2(8)$
\end{tabular}

Data presented as $n(\%)$. "At six weeks, data were available for 20 subjects, except fever, fatigue and somnolence, for which data were available for 25 subjects

\section{Study setting}

\section{METHODS}

The study was conducted at The Hospital for Sick Children, Toronto, Ontario, and The Stollery Children's Hospital, Edmonton, Alberta. The study was approved by both Institutional Research Ethics Boards.

\section{Study design and subject identification}

The present prospective study enrolled subjects who met the following criteria: $>1$ month to 25 years of age; serologically confirmed acute IM using EBV-specific serology; and a positive test for immunoglobulin M (IgM) antibodies to viral capsid antigen. Subjects were identified from inpatients admitted because of IM as well as outpatients. The latter were identified for inclusion in the study by physicians who were aware of the study when the subjects presented to the emergency departments of the two hospitals, local university health centres and physicians' offices. Information about the study was provided by the Ontario Public Health Laboratory to physicians whose patients had EBV serology consistent with acute EBV infection. Subjects were also recruited via radio messages.

\section{Clinical assessments}

All subjects underwent clinical assessments at enrollment and follow-up visits. A list of symptoms known to be associated with IM was used to grade severity of illness. This assessment strategy was modified from Rea et al (13), as originally derived from the Symptom Checklist - 90 (14). A focus was placed on symptoms and signs; measurement of health-related functional status, including but not limited to general health, mental health, social functioning and emotional well-being, were not included (13). The items and the scores used were as follows: fatigue, sore throat, painful lymph nodes, fever, somnolence, headache, sore muscles, nausea, sore joints, cough and rash. Severity was ranked from 1 to 5 , where $1=$ not at all, 2 = a little bit, 3 = moderately, $4=$ quite a bit and $5=$ extremely. Symptom scores $\geq 3$ were regarded as clinically significant. The maximum possible score was 55 (11 items $\times 5$ levels). All subjects were followed by weekly telephone contact, with a follow-up visit at six weeks. Additional visits were arranged as clinically indicated.

\section{Laboratory measurements}

Virological assays: Antibodies to viral capsid antigen (immunoglobulin $G$ [IgG] and IgM), early antigen (IgG) and Epstein-Barr nuclear antigen ( $\mathrm{IgG}$ ) were performed using ELISA methodology (DiaSorin Inc, USA) to confirm the diagnosis (15). For viral load quantitation, specimens consisting of $3 \mathrm{~mL}$ of anticoagulant (EDTA)-treated blood were processed and DNA extracted from whole blood samples using the NucliSENS easyMag system (bioMérieux, France). Real-time polymerase chain reaction for the measurement of viral load was performed using the RealStar EBV PCR Kit (Altona Diagnostics, Germany) and the RotorGene instrument (Corbett Life Science, Australia) $(16,17)$. The analytic sensitivity of the assay is 1.1 copies $/ \mu \mathrm{L}$ and the detection threshold is 275 genome copies $/ \mathrm{mL}$ of whole blood. Based on extensive

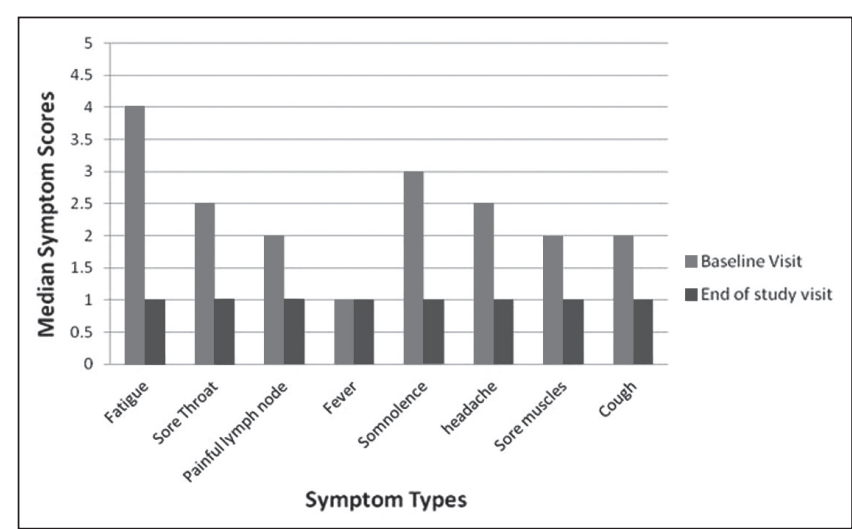

Figure 1) Illness severity scores (maximum = 5) for different symptoms/ signs at study entry and at the end of the study

experience with viral load measurements in organ transplant patients (18), viral loads of $\leq 6000$ copies $/ \mathrm{mL}$ were classified as low, $>6000$ to 30,000 as low to intermediate, $>30,000$ to 300,000 as intermediate to high and $>300,000$ copies $/ \mathrm{mL}$ as high. The viral load assays were performed in one centre (Dr Mazzulli, Mount Sinai Hospital, Toronto). Hematological assays and biochemical: All subjects underwent complete blood counts and liver function tests at enrollment and at six weeks after enrollment. More frequent testing and other investigations were performed as clinically indicated.

\section{Statistical methods}

Data were managed using Microsoft Access database and Excel (Microsoft Corporation, USA). Data were summarized using descriptive statistics and, wherever appropriate, means or medians were compared using Student's $t$ test or a nonparametric test, respectively. Proportions were compared using $\chi^{2}$ or Fisher's exact test as appropriate.

\section{RESULTS}

Descriptive characteristics

Among 32 children and young adults with acute IM, the median age was 16 years (range two to 24 years), and the male:female ratio was 1:2.6. The study subjects were symptomatic for a mean $( \pm$ SD) of $16.9 \pm 22.9$ days before initial assessment (interquartile range 15.5 days).

\section{Clinical assessments}

Table 1 summarizes the spectrum of symptoms and signs. The predominant clinical findings at presentation were lymphadenopathy (23 of 32 [72\%]), pharyngitis (16 of 32 [50\%]), splenomegaly (six of 32 [19\%]) and fever (nine of 32 [28\%]). Somnolence and fatigue were documented in $53 \%$ (17 of 32 ) and 66\% (21 of 32) of subjects, respectively. Among subjects who were available for follow-up assessment at six weeks, the predominant complaints that persisted were lymphadenopathy in seven of 20 subjects (35\%) and fatigue in four of 25 subjects (16\%). For the vast majority of subjects, splenomegaly either was not present at enrollment or had resolved by six weeks; persistence of splenomegaly was observed in $10 \%$ (two of 20 ) at six weeks.

The illness severity scoring showed the expected improvement over time, as presented in Figure 1. The median score at enrollment was 27.5 out of a maximum score of 55 (range 12 to 41), while at six weeks, the median was 12 (range 11 to 27$) ;(P<0.0001)$. As shown in Figure 1, the highest illness severity scores at baseline were primarily attributed to fatigue, somnolence, sore throat and headaches.

\section{Nonvirological laboratory assessments}

Table 2 summarizes the results of liver function tests. Blood samples at six weeks were obtained for $20(62.5 \%)$ of the 32 subjects. Sixteen percent of children $<11$ years of age and $44 \%$ of older children/youth had deranged liver function tests during the acute phase of IM. Based on the age cut-offs for normal values, among subjects $>1$ year of age, 


\begin{tabular}{|c|c|c|c|c|c|c|c|c|}
\hline \multirow[b]{3}{*}{ Liver function tests } & \multirow{2}{*}{\multicolumn{4}{|c|}{ Initial visit $(n=32)$}} & \multicolumn{4}{|c|}{ Six-week follow-up visit ${ }^{*}$} \\
\hline & & & & & \multirow{2}{*}{$\begin{array}{c}\text { Numberl } \\
\text { denominator* }(\%)\end{array}$} & \multirow[b]{2}{*}{ Mean } & \multirow[b]{2}{*}{ Median } & \multirow[b]{2}{*}{ Range } \\
\hline & n (\%) & Mean & Median & Range & & & & \\
\hline ALT (>60 IU/L) & $15(47)$ & 188.4 & 172 & $61-458$ & $2 / 20(10)$ & 709 & 709 & $72-1346$ \\
\hline AST (>36 IU/L, age $\geq 11$ years) & $13(41)$ & 131 & 107 & $36-400$ & $4 / 19(21)$ & 249 & 44 & $37-869$ \\
\hline Alkaline phosphatase (>555 IU/L) & $1(3)$ & 582 & 582 & 582 & $0 / 16(0)$ & - & - & - \\
\hline Total bilirubin (>19 $\mu \mathrm{mol} / \mathrm{L})$ & $5(16)$ & 50.6 & 37 & $21-97$ & $1 / 14(7)$ & 38 & 38 & 38 \\
\hline
\end{tabular}

*Data availability at six weeks (denominators): Alanine transaminase (ALT), $n=20$; aspartate transaminase (AST), $n=19$; alkaline phosphatase $n=16$; bilirubin, $n=14$; gamma-glutaryl transferase, $n=7$

the median alanine transaminase (ALT) level was 198 IU/L (range $61 \mathrm{IU} / \mathrm{L}$ to $458 \mathrm{IU} / \mathrm{L}$ ), while the median aspartate transaminase (AST) level was $179 \mathrm{IU} / \mathrm{L}$ (range $51 \mathrm{IU} / \mathrm{L}$ to $771 \mathrm{IU} / \mathrm{L}$ ). Thirty-one percent of subjects had ALT values that were at least twice the upper limit of normal at presentation, while the corresponding percentage for AST was $6 \%$ and $22 \%$ for subjects one to $<11$ and $\geq 11$ years of age, respectively. At six weeks, one of 20 evaluable patients still had transaminase levels that were at least twice the upper limit of normal. One subject was identified who developed autoimmune hepatitis that was triggered by EBV and which led to a liver biopsy and treatment with corticosteroids after initial treatment with acyclovir.

Assessment of hematological parameters at initial presentation indicated neutrophil counts $<1 \times 10^{9} / \mathrm{L}$ in $12.5 \%$ (four of 32 ) of patients and lymphocyte counts $<1.5 \times 10^{9} / \mathrm{L}$ in $15.6 \%$ (five of 32 ) patients. Thrombocytopenia (platelet count $<150 \times 10^{9} / \mathrm{L}$ ) was observed in four $(12.5 \%)$ of 21 subjects; the median platelet count was $227 \times 10^{9} / \mathrm{L}$ (range $1 \times 10^{9} / \mathrm{L}$ to $\left.380 \times 10^{9} / \mathrm{L}\right)$. These hematological abnormalities had resolved among the subjects who were available for testing at the six-week visit.

Viral loads in relation to clinical and laboratory variables

The median viral load at the initial visit for all subjects was 5180 copies/mL (range 0 copies $/ \mathrm{mL}$ to 926,014 copies $/ \mathrm{mL}$ ). This median viral load value would be categorized as low based on the assay. There was no significant relationship between the age of the study subjects and their viral loads at the time of enrollment $(r=-0.025 ; \mathrm{P}=0.91)$. Similarly, viral loads at the time of enrollment were not associated with the duration symptoms before presentation $(\mathrm{r}=-0.25 ; \mathrm{P}=0.24)$. The relationship between viral loads $\left(\log _{10}\right)$ at enrollment and laboratory indexes indicated no significant correlation between loads and the following: hemoglobin level ( $r=0.35 ; \mathrm{P}=0.09)$, white blood cell count $(\mathrm{r}=-0.24 ; \mathrm{P}=0.26)$, neutrophil counts $(\mathrm{r}=0.18 ; \mathrm{P}=0.39)$, lymphocyte counts $(\mathrm{r}=-0.29 ; \mathrm{P}=0.17)$, platelet counts $(\mathrm{r}=-0.12 ; \mathrm{P}=0.52)$, AST level $(\mathrm{r}=-0.10 ; \mathrm{P}=0.66)$ and ALT level $(\mathrm{r}=-0.01 ; \mathrm{P}=0.95)$.

Among 27 patients with complete pairs of viral load values and severity scores, there was only weak correlation $(r=0.29)$ between viral loads at baseline and symptom severity scores for fatigue (Figure 2). However, subjects with intermediate to high levels of viral load ( $>30,000$ copies $/ \mathrm{mL}$ ) were more likely to have fatigue symptom scores of 4 or 5 , compared with those with lower viral loads (six of six versus nine of $21 ; \mathrm{P}=0.02$ ). Among subjects who had viral load values obtained at the initial visit and at the end of the study period $(n=17)$, the median viral load at the initial visit was $5750 \mathrm{copies} / \mathrm{mL}$ (range 0 copies $/ \mathrm{mL}$ to 174,000 copies $/ \mathrm{mL}$ ). The corresponding values at follow-up were 663 copies $/ \mathrm{mL}$ (range 0 copies $/ \mathrm{mL}$ to 171,000 copies/mL; $\mathrm{P}=0.13$ ). However, viral load assessments were not significantly correlated with improvement in overall symptom scores over time $(\mathrm{r}<0.3)$.

\section{DISCUSSION}

We have documented the spectrum of clinical and laboratory manifestations in a cohort of children and youth with primary EBV infection. We assumed that our study centres were likely to have attracted individuals with the more severe end of the spectrum of primary EBV infection because individuals with milder degrees of infection would

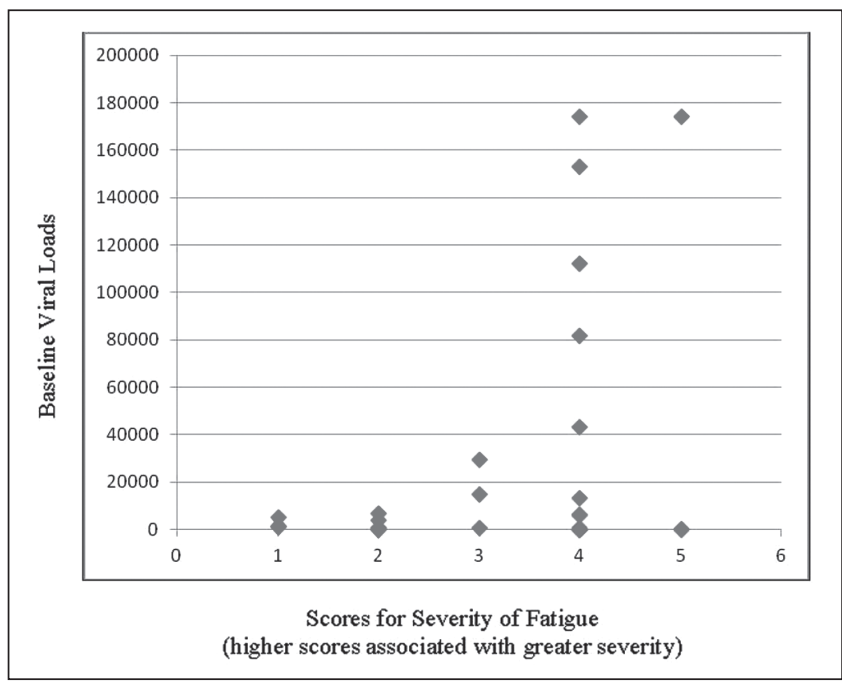

Figure 2) Baseline viral loads in relation to illness severity scores associated with fatigue. Patients with with intermediate to high levels of viral load were more likely to have fatigue symptom scores of 4 or 5 , compared with those with lower viral loads $(P=0.02)$

either not have presented to their physicians or, if seen, would be less likely to have been referred. The presence of certain complications was presumed to be consistent with more severe forms of primary EBV; these include, but are not limited to, encephalitis, hemophagocytosis and hepatitis $(19,20)$.

During the acute phase of IM, reported rates of sore throat typically range from $75 \%$ to $90 \%$. Fifty percent of our study subjects complained of sore throat and fatigue. Compared with other studies $(6,13)$, the frequency of the occurrence of fever was low in our study and likely reflects the interval between the onset of illness and enrollment in the study. Assessment at six weeks indicated that lymphadenopathy and fatigue were among the findings that were slowest to resolve. Although splenomegaly was only present in a minority of subject at six weeks, this is of clinical importance in the counselling of patients because this relates to the avoidance of contact sports during this time frame, given the well-known potential for splenic rupture following IM.

We demonstrated the presence of hepatitis in a significant proportion of patients at enrollment. Hepatitis is known to be a complication of IM, although the magnitude is not well documented in prospective studies that incorporate viral load measurements. The condition is usually benign, but fulminant hepatitis has been documented $(21,22)$. Our findings are similar to a prospective study by Rea et al (13), in which $31 \%$ and $61 \%$ of their patients had abnormal ALT and AST levels at their initial visits. Typically, the abnormal transaminase values are in the mildly elevated category $(13,23-28)$. However, as shown in our study, these values may be moderate or more significantly elevated. While in both studies, liver function tests typically normalized by six weeks, prolonged abnormalities may occur. Such prolonged liver function abnormalities may herald the onset of 
autoimmune hepatitis, as was documented in our study. Typically, subjects recovered without antiviral therapy. In our cohort, one patient had hepatitis that was deemed sufficiently severe to warrant antiviral therapy (and subsequently corticosteroids for autoimmune hepatitis).

The kinetics of viral load in IM was studied during primary infection by Balfour et al (23). These investigators demonstrated that the median half-life of viral elimination from whole blood was three days (mean 3.4 days, range 1.8 to 6.6 days). This was consistent with our findings that indicated that the majority of subjects had low or undetectable viral loads by the time they presented with a clinical diagnosis of IM. The vast majority of subjects became asymptomatic within six weeks. However, given that oropharyngeal shedding of EBV is known to persist beyond the acute phase of primary EBV, even if the virus has been cleared from the peripheral blood (23), it is likely that asymptomatic study subjects were still shedding virus well into the convalescent period.

In the above context, persistence of detectable viral loads in the peripheral blood may help to define a subgroup of patients who are less able to contain viral load. In such situations, the occurrence of prolonged high viral loads could be considered to represent an abnormal state that is not consistent with what would be expected in an individual with the ability to contain EBV replication. This notwithstanding, prolonged illness may occur despite containment of viral load (29). In our study, subjects with the highest viral load were more likely to have higher illness severity scores relating to fatigue. However, while those with detectable viral loads experienced improvement in such loads over time, the loads were not correlated with the magnitude of the overall illness severity scores. This is consistent with the situation that commonly occurs in immunocompromised hosts, who may have prolonged periods of high

\section{REFERENCES}

1. Epstein MA, Achong BC, Barr YM. Virus particles in cultured lymphoblasts from Burkitt's lymphoma. Lancet 1964;15:702-3.

2. Fry J. Infectious mononucleosis: Some new observations from a 15-year study. J Fam Pract 1980;10:1087-9.

3. Henke CE, Kurland LT, Elverback LR. Infectious mononucleosis in Rochester, Minnesota, 1950 through 1969. Am J Epidemiol 1973;98:483-90.

4. Rickinson AB, Kieff E. Epstein-Barr virus. In: Fields BN, Klipe DM, Howley PM, et al, eds. Fields Virology, 4th edn. Philadelphia: Lippincott - Raven Publishers, 2001;2575-627.

5. Leach CT, Sumaya CV. Epstein-Barr virus. In: Cherry JD, Feign RD, eds. Textbook of Pediatric Infectious Diseases, 5th edn. Philadelphia: WB Saunders Company, 2004;1932-56.

6. Sumaya CV, Henle W, Henle G, et al. Seroepidemiologic study of Epstein-Barr virus infections in a rural community. J Infect Dis 1975;131:403-8.

7. Henle W, Henle G. Epidemiologic aspects of Epstein-Barr virus (EBV)-associated diseases. Ann NY Acad Sci 1980;354:326-31.

8. Sumaya CV, Ench Y. Epstein-Barr virus infectious mononucleosis in children. I. Clinical and general laboratory findings. Pediatrics 1985;75:1003-10.

9. Cohen JI. Epstein-Barr virus infection. N Engl J Med 2000;343:481-92.

10. Fisman DN. Hemophagocytic syndromes and infection. Emerg Infect Dis 2000;6:601-8.

11. Weitzman S, Egeler RM. Histiocytic disorders of children and adults: Introduction to the problem, overview, historical perspective and epidemiology. In: Weitzman S, Egeler RM, eds. Histiocytic Disorders of Children and Adults. Cambridge: Cambridge University Press, 2005;1-10.

12. Weinstein M, O'Hare B. Hemoptysis and Epstein-Barr virus infection. Pediatr Infect Dis J 2000;8:760-1.

13. Rea TD, Russo JE, Katon W, et al. Prospective study of the natural history of infectious mononucleosis caused by Epstein-Barr virus. J Am Board Fam Pract 2001;14:234-42.

14. Derogatis LR. The SCL-90 Manual 1: Scoring, administration, and procedure for the SCL-90. Baltimore: Clinical Psychometrics Unit, John Hopkins University, 1977.

15. Gärtner BC, Hess RD, Bandt D, et al. Evaluation of four commercially available Epstein-Barr virus enzyme immunoassays with an immunofluorescence assay as the reference method. Clin Diagn Lab Immunol 2003;10:78-82.

16. Mackay IM. Real-time PCR in the microbiology laboratory. Clin Microbiol Infect 2004;10:190-212. viral loads following primary EBV infection without such loads being correlated with the severity of their symptoms $(30,31)$.

We have summarized the characteristics of the more severe forms of primary EBV encountered in our study. For example, we have documented profound thrombocytopenia, severe neutropenia and significantly elevated transaminase levels. We were unable to document an association between these variables and viral loads, but we do acknowledge that the sample size was a limitation of our study. A larger study would also enable the determination of the full spectrum of the more extreme clinical presentation of IM, and would be better able to detect some of the more uncommon severe complications of IM. This notwithstanding, we have determined the more common clinical and laboratory correlates of primary EBV infection deemed sufficiently severe to present to centres such as ours. These findings will help with the assessment of immunocompromised patients in whom these clinical and laboratory markers of primary EBV (eg, hepatitis) may be more profound. We plan to perform additional studies to determine the genotypic correlates of the more severe presentations of primary EBV in immunocompetent hosts. An understanding of such markers of severity would also be of relevance to some immunocompromised hosts in whom the effects of intrinsic susceptibility to severe EBV infection may be exaggerated by iatrogenic immunosuppression $(30,31)$.

ACKNOWLEDGEMENTS: The authors appreciate the work of research nurses, Denise Ho and Marie Claire, as well as others who were involved in the enrollment of subjects. The study was funded in part by a research grant from the Canadian Institutes of Health Research (grant \#MOP86685).

17 Rotor-Gene 6000. <www.corbettlifescience.com/control-RotorGene_6000_6-0196.html> (Accessed September 8, 2011).

18. Allen UD, Hébert D, Tran D, et al. Utility of semiquantitative polymerase chain reaction for Epstein-Barr virus among pediatric solid organ transplant recipients with and without post-transplant lymphoproliferative disease. Clin Infect Dis 2001;33:145-50.

19. Cohen JI. Chapter Five. Clinical aspects of Epstein-Barr virus infection. In: Robertson ES, ed. Epstein-Barr Virus. Norfolk: Caister Academic Press, 2005:34-54.

20. Andersson J. Chapter Six. Clinical features of infectious mononucleosis. In: Epstein-Barr virus. Tselis A, Jensen HB, eds. New York: Taylor and Francis Group, 2006:99-124.

21. Fuhrman SA, Gill R, Horwitz CA, et al. Marked hyperbilirubinemia in infectious mononucleosis. Analysis of laboratory data in seven patients. Arch Intern Med 1987;147:850-3.

22. Devereaux CE, Bemiller T, Brann O. Ascites and severe hepatitis complicating Epstein-Barr virus infection. Am J Gasteroenterol 1999;94:236-40.

23. Balfour $\mathrm{HH}$, Holman CJ, Hokanson KM, et al. A prospective clinical study of Epstein-Barr virus and host interactions during acute infectious mononucleosis. J Infect Dis 2005;192:1505-12.

24. Horowitz CA, Burke MD, Grimes P, et al. Hepatic function in mononucleosis induced by Epstein-Barr virus and cytomegalovirus. Clin Chem 1980;26:243-6.

25. Dunnet WN. Infectious mononucleosis. BMJ 1963;1:1187-91.

26. Mason WR Jr, Adams EK. Infectious mononucleosis: An analysis of 100 cases with particular attention to diagnosis, liver function tests and treatment of selected cases with prednisone. Am J Med Sci 1958;236:447-59.

27. Gelb D, West M, Zimmerman HJ. Serum enzymes in disease. IX. Analysis of factors responsible for elevated values in infectious mononucleosis. Am J Med 1962;33:249-61.

28. Vine LJ, Shepherd K, Hunter JG, Madden R, et al. Characteristics of Epstein-Barr virus hepatitis among patients with jaundice or acute hepatitis. Aliment Pharmacol Ther 2012;36:16-21.

29. Cameron B, Bharadwaj M, Burrows J, et al. Prolonged illness after infectious mononucleosis is associated with altered immunity but not with increased viral load. J Infect Dis 2006;193;664-71.

30. Allen U, Preiksaitis J. Epstein-Barr virus and post-transplant lymphoproliferative disorder. Am J Transplant 2013;13:107-13.

31. Allen UD, Green M. Prevention and treatment of infections after pediatric solid organ transplantation. Pediatr Clin North Am 2010;57:459-79. 


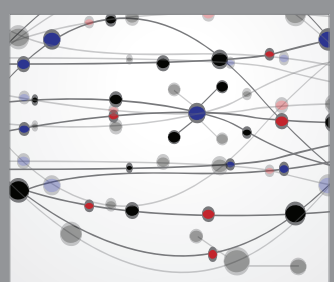

The Scientific World Journal
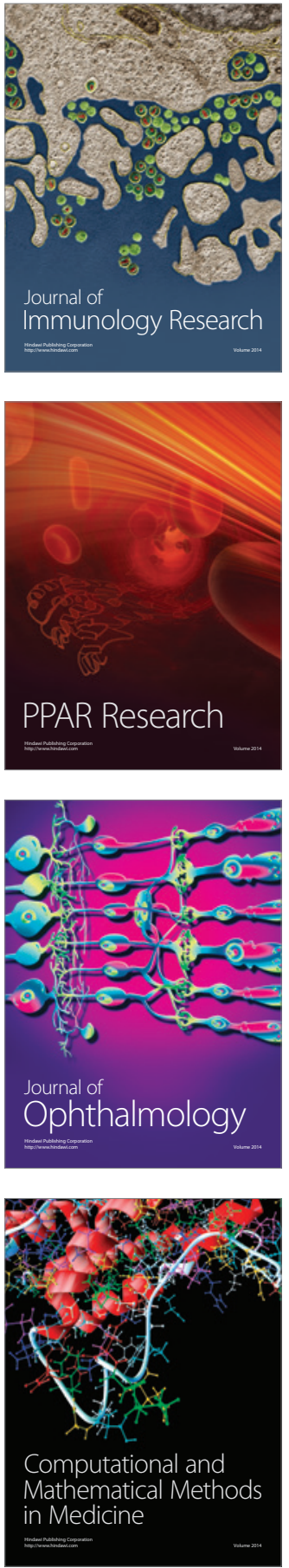

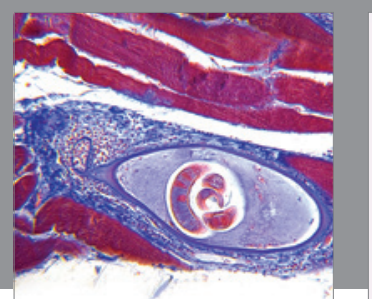

Gastroenterology Research and Practice

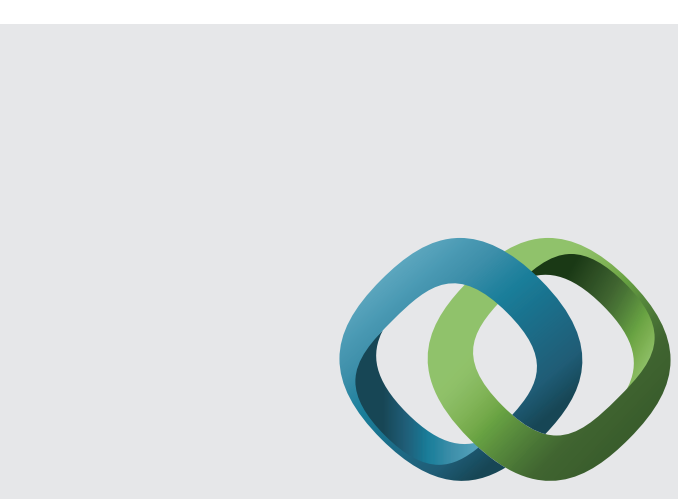

\section{Hindawi}

Submit your manuscripts at

http://www.hindawi.com
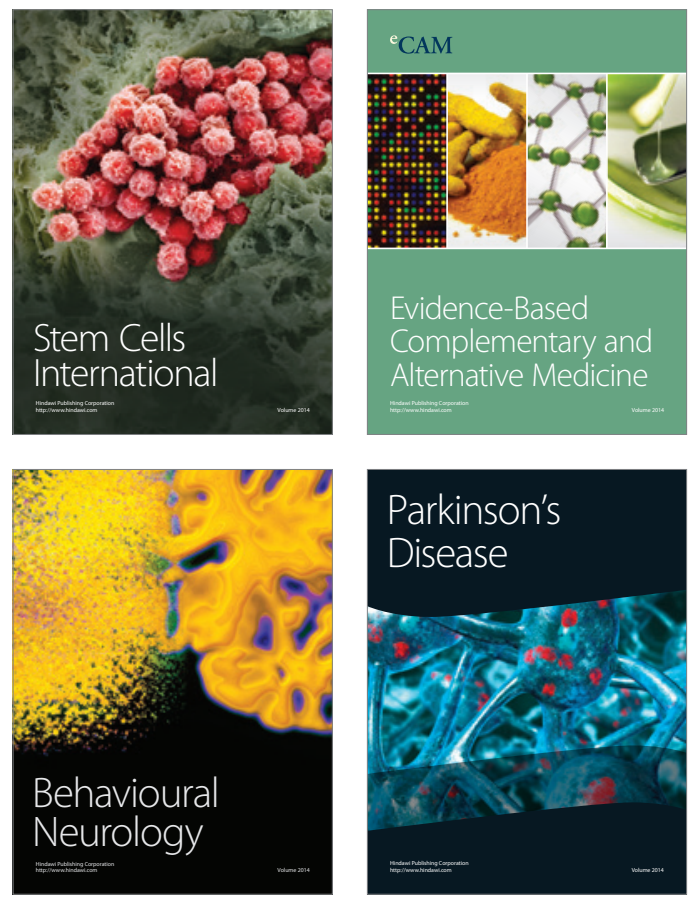
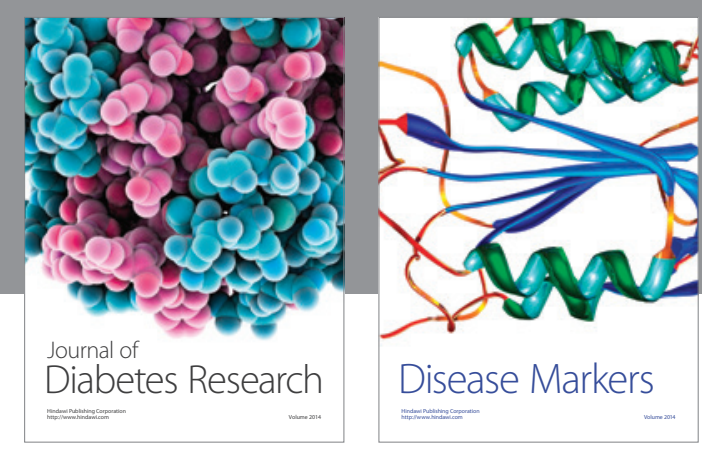

Disease Markers
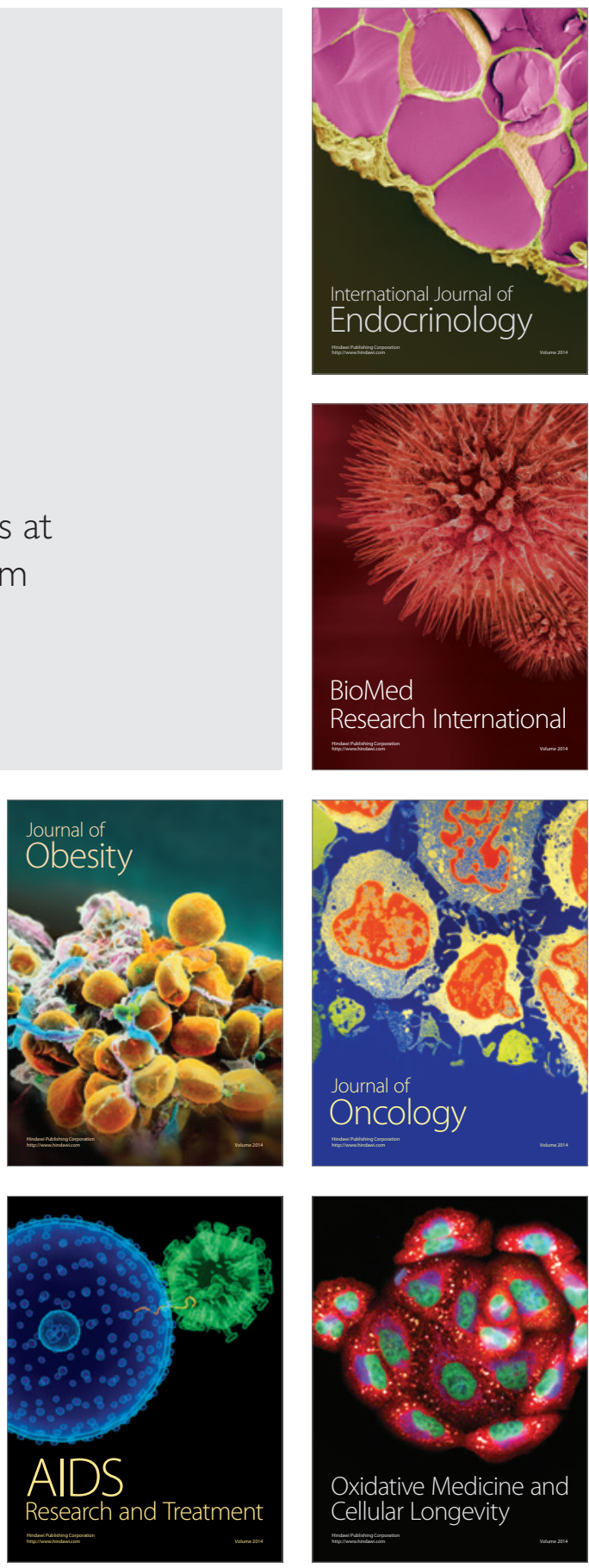